\title{
ECO-INNOVATION, A BUSINESS APPROACH TOWARDS SUSTAINABLE PROCESSES, PRODUCTS AND SERVICES
}

\author{
Aida Szilagyi $^{1}$, Andrei Churican ${ }^{1}$, Anne Verniquet $^{2}$, David Rochat ${ }^{2}$
}

1 National Centre for Sustainable Production and Consumption, 6 Madrid St., aida.szilagyi@cnpcd.ro, Timisoara, Romania

${ }^{2}$ Association Genovese for Development of Circular Economy AGEDEVE, 19a Rue Centrale, 1247, Anieres, Switzerland

\begin{abstract}
Eco-innovation has been widely accepted as a method for improving the performance of enterprises and for supporting them to advance to more sustainable business models, as well as a driver of business success and competitive advantage at the firm level.Implementing ecoinnovation is a challenging process and will not be suitable for all organisations. Therefore understanding barriers and drivers at the national and business level and main gaps in policy and education could build a better picture of the context and conditions for eco-innovation in Romania. The paper reflects existing opportunities in the country and demonstrates that ecoinnovation potential is important and needs to be addressed. Our research identified existing premises and drivers for eco-innovation that could boost application of eco-innovation in companies, entail policy changes, and boost cooperation between stakeholders from $R \& D$, academia, businesses, clusters and policy makers. The succes of eco-innovation depends on the awareness that will be created among businesses through dissemination of strong business cases, the adjustment of the policy framework that should stimulate and reward the market for eco-innovative solutions and the capacity of experts to convince the companies' management of the financial and environmental benefits of eco-innovation, to explain the need for continuous application of eco-innovative strategies and how they can be mainstreamed in the overall enterprise strategy and overall management. Through its objectives, the ECOPartner project contributes to install a model of cooperation betwen main actors interested in eco-innovation and build cooperation between the main stakeholders by initiating the Romanian Eco-Innovation Network (RE-IN). The role of the RE-IN is to develop and strengthen partnerships and to become the main partner in Romania for policy makers, businesses, academia and experts with common interests in eco-innovation.
\end{abstract}

Keywords: business, eco-innovation, strategy, sustainabilty

\section{Introduction}

The objectives of this article are introduce the main arguments (the why, the what and the how) for adoption of eco-innovation at the enterprise level as explained by international organizations and demonstrated through various business cases and examples and to present the results of the research performed to identify the context, the barriers and the drivers for eco-innovation in Romania.

\section{Why eco-innovation?}

Today, humanity uses more natural resources than the earth can sustain on the long run. The bio-capacity of the earth (including both extraction and absorptive capacity for waste and emissions) has already been exceeded by around 50\% [1]. In 2015, the "Earth Overshoot Day" fell on August 13nd, which means that humanity has exhausted 
the natural resources for a full year within only 8 months. Since 1950, not only the world's population but also every societal and economic activity has grown exponentially. The International Geosphere-Biosphere Programme and Stockholm Resilience Centre has published a dashboard of 24 indicators which depict the dramatic acceleration in human enterprise and the impacts on the Earth system over the last two centuries. What is apparent is the synchronous acceleration of trends from the 1950s to the present day - over a single human lifetime - with little sign of abatement. These trends are known as the Great Acceleration. 12 socio-economic and 12 Earth system trends from 1750 to present- are strong evidence that the Earth system has moved to a new state. Changes in human production and consumption, indicated by gross domestic product, direct foreign investment, energy consumption and telecommunications, are reflected in changes in the Earth's natural systems: climate (greenhouse gas levels, global temperature), ocean acidification, terrestrial biosphere degradation and fish capture [1].

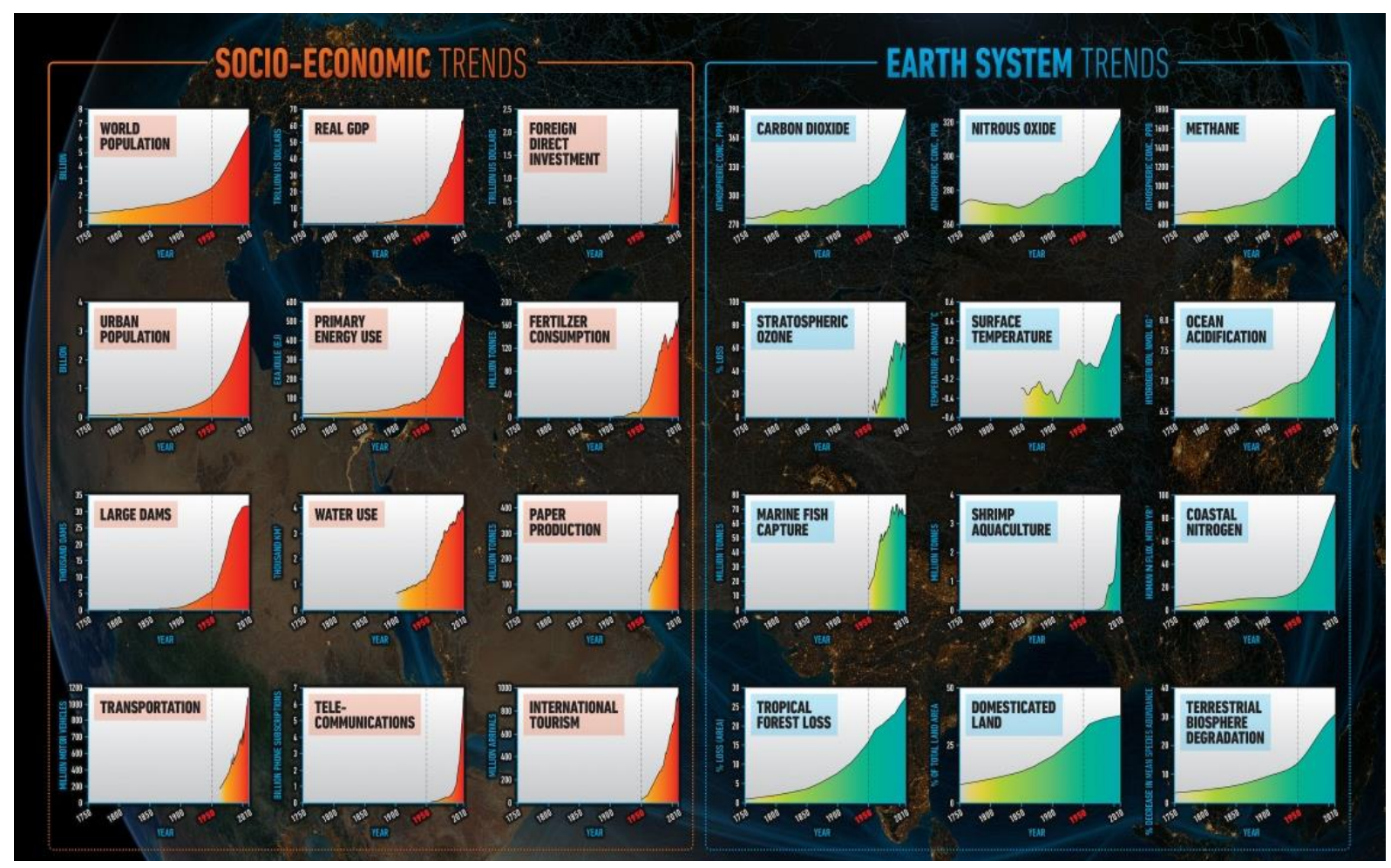

Figure 1: The trajectory of the Anthropocene: the great acceleration. Article from W. Steffen, W. Broadgate, L. Deutsch, O. Gaffney and C. Ludwig (2015), figure redraw from http://www.futureearth.org/blog/2015-jan-16/great-acceleration

This economic development comes with price of unprecedented materials consumption and impact pollution, as a result, $60 \%$ of the benefits provided by global ecosystems to support life on Earth (such as fresh water, clean air and a relatively stable climate) are being degraded or used in an unsustainable way, based on the Millennium Ecosystem Assessment [2].

The sustainability challenges (climate change, resource scarcity, environmental degradation, worker welfare) in recent decades, give rise to drivers for change in the way that companies operate. Sticking with the 'Business as usual' approach will leave companies unable to respond to issues such as rising costs of resources, disruptions 
to supply of their raw materials or changes in legislation. There is therefore, a growing need to find alternative approaches that can help to address businesses and products sustainability, whilst at the same time offer opportunities for growth, cost reduction and competitive advantage [1].

It is widely acknowledged that innovation is a driver of economic and social progress on a national level, as well as a driver of business success and competitive advantage at the firm level. However, if countries want to move towards a more ecologically sound and prosperous society, it is important to promote the right kinds of innovation. Such innovation should open up new ways of addressing current and future environmental problems and of decreasing energy and resource consumption, while promoting sustained economic activities. This type of innovation is referred to as eco-innovation. The business case for systemic eco-innovation is now widely accepted. The global market for low-carbon products is already estimated to be worth over USD 5 trillion and growing. In 2009, Walmart, the largest retailer in the world, introduced a worldwide sustainability index. The index will be applied to over 100000 global suppliers to give consumers a clear environmental and social rating for every product it sells. A green reputation drives up your financial value; A study by Harvard and London Business Schools found that financial analysts rate companies with a visible reputation for environmental responsibility higher than others. Conversely, poor performance can be a serious risk. A little investment in greening may lead to big savings; The UK's Carbon Trust estimates that most businesses can cut their energy bills by up to $20 \%$ with only a small investment - a saving that could equate to as much as a $5 \%$ increase in your overall profits. Young workers value sustainability and demand green workplaces; A 2010 survey of 5300 respondents worldwide, carried out by Johnson Controls Global Work Place Solutions, shows that over $96 \%$ of $18-45$ year olds want their employer and workplace to be environmentally friendly or at least environmentally aware [3]

\section{What is eco-innovation?}

Eco-innovation encompasses strategies to decouple economic growth from environmental degradation and achieve greater resource efficiency. It aims at doing more and better with less across the entire life cycle of products.

At its core, eco-innovation is about creating business models that are both competitive and respect the environment by reducing resource intensity of products and services. It is about creating resilient business models that generate value along the all value chain: new markets and customers, additional value captured by the focal organization(s) like cost savings or cost avoidance, new value captured by the partners. It is about extending your business model. Eco-innovation can be seen as both overarching objective for sustainable development and offering a wide range of concrete operational approaches targeting different sectors and various market players. In the view of WBCSD group, opportunities range from developing and maintaining low-carbon, zero-waste cities and infrastructures to improving and managing ecosystems and lifestyles. These changes are also considered to create opportunities for the finance and ICT sectors [4].

Eco-innovation targets can be either processes or products (e.g. Michelin energy saving tires), organizations and marketing methods (e.g. Xerox managed print services) or institutions (e.g. Vélib Bike sharing in Paris). Eco-innovation relies on various mechanisms, from interventions at the process level or simple product modification to re-design to alternatives and creation or new marketing and business models. 


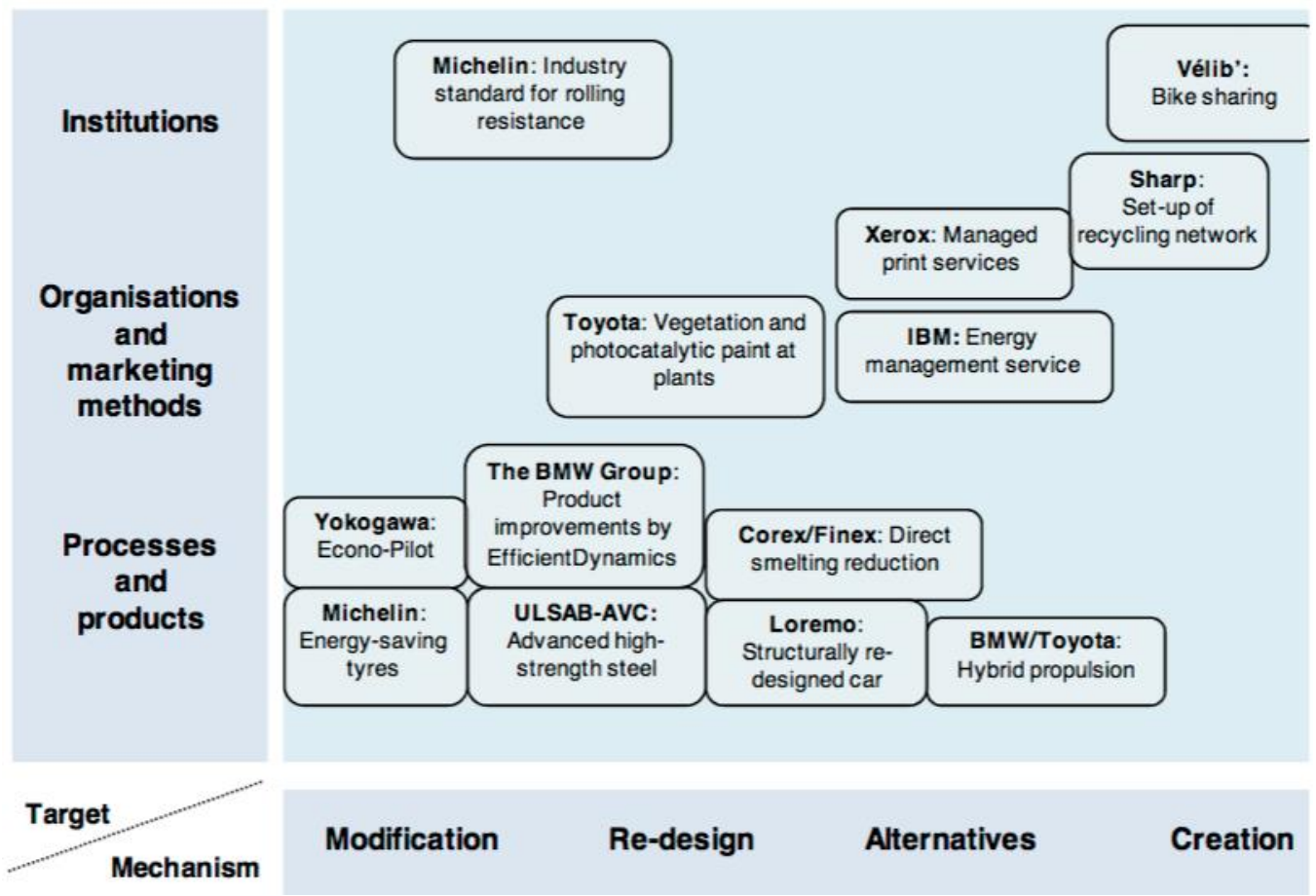

Figure 2: Mapping the primary focus of example of eco-innovation, OECD Sustainable Manufacturing and eco-innovation, Framework, Practices and Measurement, Synthesis report, 2009

\section{What are the key success factors to boost eco-innovation at a country level?}

It is possible for a country to try to create favorable conditions for emergence of systemic eco-innovation. Different intertwined layers of interventions are required. At country level, a strong vision and awareness is a pre-requisite, with a clear strategy and targets to address societal challenges (eco-innovation macro-indicators) and a strong promotion of sustainable consumption and production practices. Moreover, general framework conditions (degree of voids, easiness to do business, easiness to innovate) are essential factors to facilitate innovation as well as eco-innovation. Infrastructures and technologies can be designed FOR systemic eco-innovation. The structural context of a country has indeed direct impacts on the deployment of environmentally sound measures in companies, at inputs, operations or products levels. The policy mix can also be designed for systemic eco-innovation; Integration of innovation and environmental policies is crucial for promoting eco-innovation along the all innovation cycle (Dries et al. (2005), in OECD (2005b). Generally, innovation policy in most countries has been the responsibility of ministries for trade and industry and science and technology, while environmental policy has usually been developed by environment ministries. Few efforts have so far been made to integrate these two policy domains. Environmental policies have traditionally focused on treatment of pollution and waste, and thus on end-of-pipe solutions, rather than on the whole production and disposal processes. Innovation policy, on the other hand, has been too broad to address specific environmental concerns appropriately. Recently, some marketoriented instruments, such as green taxes and tradable permits, have been introduced as measures that put a price on the "bad". However, to realize its potential, ecoinnovation will require actions to ensure that the full cycle of innovation is efficient, with 
policies ranging from appropriate investments in research to support for commercializing existing and breakthrough technologies.

Both environmental and innovation policy areas would benefit from closer integration. At market level, a mix of market based instruments can be designed FOR ecoinnovation, with demand measures (regulations and standards, public procurement and demand support, technology transfer) and supply side measures (equity support, research and development (R\&D), education and training, networks and partnerships, provision of infrastructure)

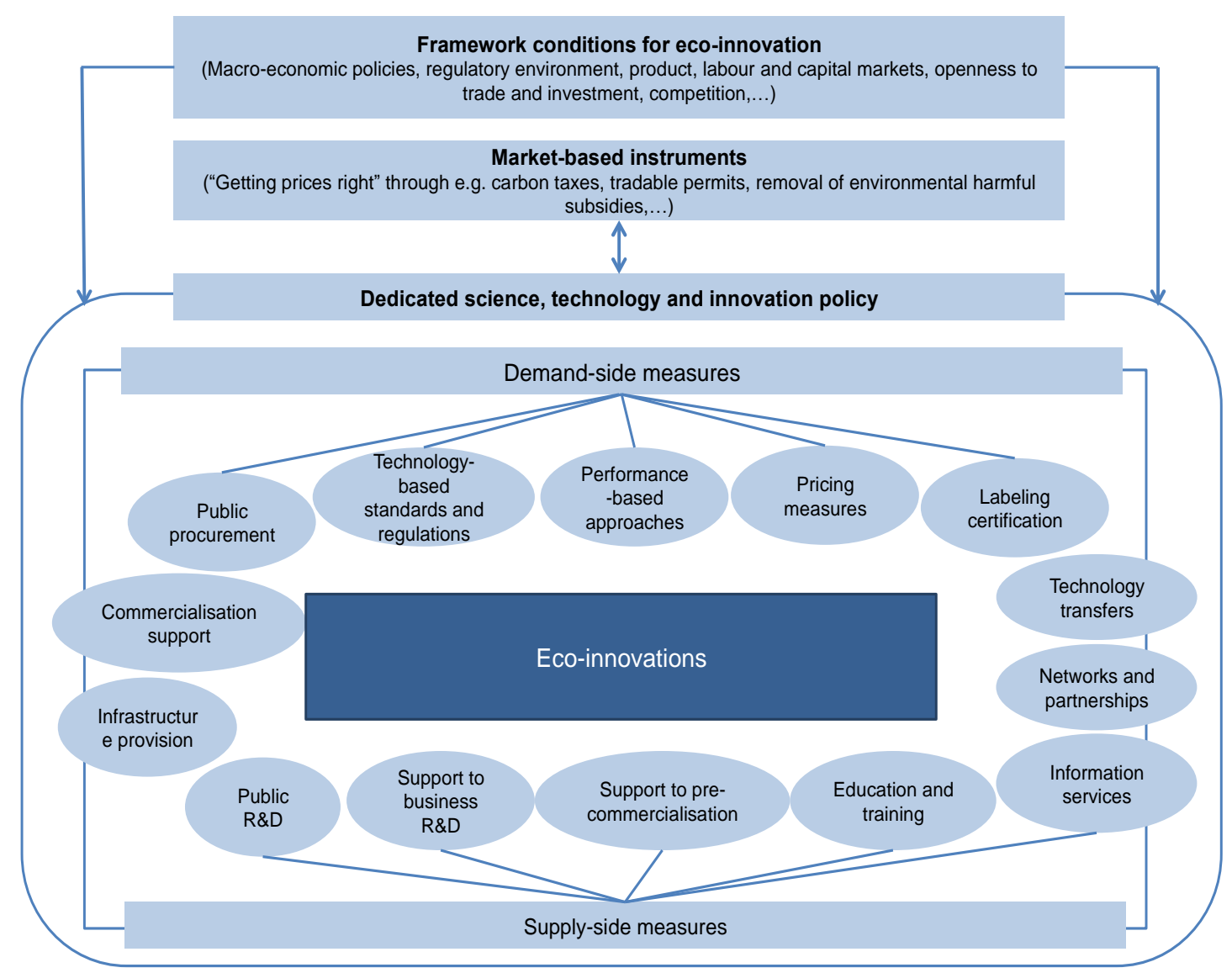

Figure 3: Framework conditions for eco-innovation, Business Models for Systemic Ecoinnovations, Final Report, Feb. 2012, Technopolis Group

\section{Materials and Methods}

The aim of the study was to identify the enabling conditions, challenges, threats and opportunities for eco-innovation in Romania. The study was concentrated on four main parts: 1) analyze of the existing context in Romania: the natural capital, the ecoinnovation scoreboard; 2) the research and innovation context 3) the policy context; 4) based on the performed analysis summing up barriers and drivers for eco-innovation The desk research considered existing national and regional environmental reports of the NEPA/EPA describing the Romania's natural capital, sectors and markets with high direct environmental impact, national strategies, and international reports, national and European statistics. 
The study has been performed based on desk research, a survey addressed to a significant number of identified stakeholders and direct consultations during meetings and seminars. The survey investigated the existing experience in eco-innovation or related areas, the interest of organizations in increasing their technical capacity or building capacity, their capabilities of offering expert support to the companies, developing their own eco-innovative businesses or intervening at the policy level. The survey questionnaire has been sent out to more than 120 organizations consisting of research institutions, academia, clusters, associations and consultancies. Out of which, 30 provided their responses. The relatively low level of response rate $(25 \%)$ is based mainly on the lack of experience in the investigated areas by the addressed organizations, confirming the fact that eco-innovation is not yet part of their priorities.

\section{The national context in Romania}

Romania is not an exception from the global situation. Comparing the availability of natural resources in Romania with the EU average, data from 2008 - 2015 showed that the country is facing shortage of potable water sources $(2.660 \mathrm{~m} 3$ / capita / year of usable water, compared to $4000 \mathrm{~m} 3$ / capita / year, the EU average ${ }^{1}$ ); lower forest coverage due to deforestation in the latest years (23\% comparing to $40-45 \%$ optimum level ${ }^{2}$ ); $52 \%$ of soil has low or very low fertility, due to irrational agricultural exploitation, industrial pollution and waste landfilled while the bio productive capacity of the natural capital is estimated at $2.17 \mathrm{~g} \mathrm{ha/capita} \mathrm{(natural} \mathrm{productive} \mathrm{area/} \mathrm{capita)} \mathrm{below} \mathrm{the}$ socio-economic footprint of $2.7 \mathrm{~g} \mathrm{ha} /$ capita $^{3}$ (2006).

Moreover, according to Eurostat data, the Romanians economy is characterised by low resource efficiency, expressed as a level of 0.327 EURO/kg ${ }^{4}$ GDP/domestic material consumption), compared with the EU average of $1.966 \mathrm{EURO} / \mathrm{kg}$. The energy intensity of the Romanian economy was $235.5 \mathrm{~kg}$ oil equivalent/1000 EURO GDP in 2014, comparing the EU 28 average of $122 \mathrm{~kg}$ oil equivalent/1000 EURO GDP 5 . As figures shows, Romania's performances are well below the EU average level, although the country is engaged towards transformation to a green economy according to latest commitments (signatory of bigE Initiative ${ }^{6}$, green economy as country priority since January 2016)

Although there is no specific eco-innovation policy in Romania, a number of laws transposed from the European directives are imposing more demanding requirements referring to: energy efficiency, waste prevention and reduction or producer's responsibility. While big companies are starting to include elements of eco-design in their products, particularly required by legislation in force, (e.g., energy efficient household equipment, elimination of hazardous substances content in electronic and electric equipment, requirements for reusable/recyclable packaging, etc.), the SME's are still confronted with various obstacles such as: lack of environmental awareness, low capacity of understanding life cycle thinking and derived economic benefits that

\footnotetext{
12008: http://www.un.org/esa/dsd/dsd_aofw_ni/ni_pdfs/NationalReports/romania/Romania.pdf

2 2014: http://hrmars.com/hrmars_papers/IJAREG_1_1_art_07_Bran_FI2.pdf

3 2009: pg7. http://www.enciclopedia-economica.ro/upload/files/AT_SOLULROMANIEI-2-2-1-wordprezentareSOL-acad-Hera.pdf

${ }_{4} \mathrm{http}: / /$ ec.europa.eu/eurostat/documents/2995521/7051895/8-27102015-AP-EN.pdf/bfe65bed-cd9247f3-a316-7d59c7b2e504

${ }^{5} \mathrm{http}: / /$ ec.europa.eu/eurostat/tgm/table.do?tab=table\&init=1\&language=en\&pcode=tsdec360\&plugin=1

${ }^{6}$ Batumi Green Economy Initiative
} 
arise from eco-innovative approaches, insufficient access to specific information and education.

\section{The status of eco-innovation in Romania}

According to the Eco-Innovation Observatory report, "Eco-Innovation in Romania, Country Profile 2013, the main issue is not the resource scarcity, but rather the lack of efficient management of the available resources that can have important implications on the country's economy and sustainable development.

In 2015 Romania is ranked 18th in the EU Eco-innovation scoreboard with a score of 82, below the EU28 average score of $100^{7}$ but it has advanced three positions since 2013, from the previous rank of 21 [5].

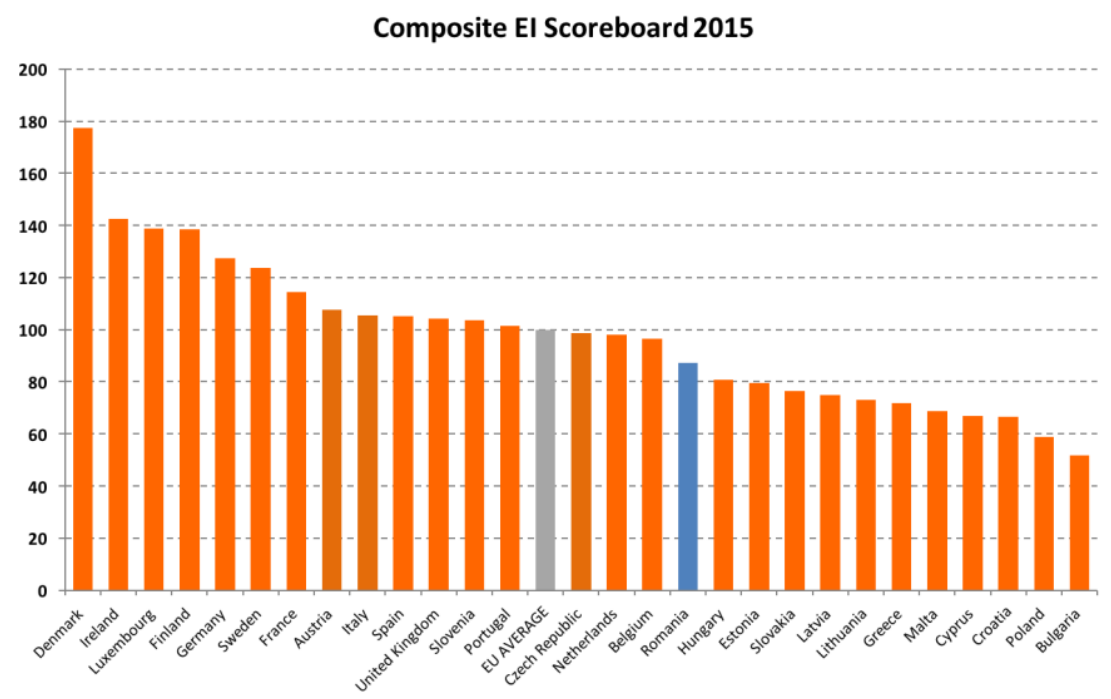

Figure 4: EU28 Eco-innovation scoreboard 2015, composite index, figure redraw from https://ec.europa.eu/environment/ecoap/sites/ecoap stayconnected/files/romania ecoinnovation 2015.pdf

According to the European Eco-innovation Observatory, the main components of ecoinnovation are based on eco-innovation inputs and outputs, eco-innovation activities, resource efficiency outcomes and socio economic outcomes [5]. The general overview of the eco-innovation situation in Romania represented in figure 2 clearly reflects that in the absence of inputs, the results in the field of eco-innovation are under the EU averages. Information and knowledge is relatively available but not used. There are three main reasons for this situation:

- the Romanian business sector is characterized by a short-sighted perspective on profit making;

- $\quad$ the R\&D activities are not responding to the current economic, environmental and societal needs;

- the regulatory framework is not providing incentives for eco-innovative practices, products and services. 


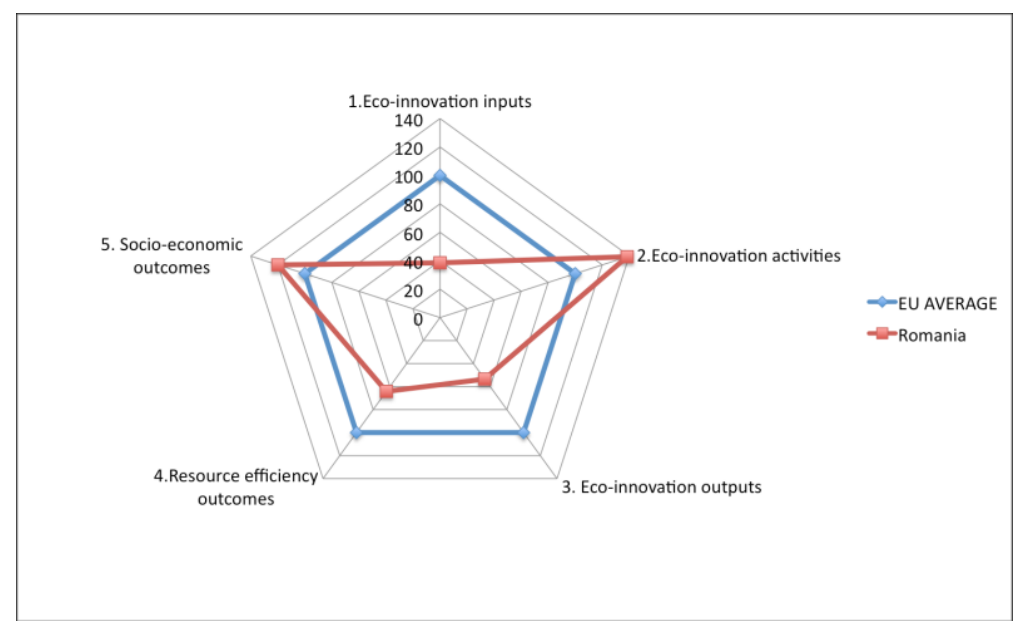

Figure 5: Components of the eco-innovation composite index for Romania, versus EU average (2015),

https://ec.europa.eu/environment/ecoap/sites/ecoap stayconnected/files/romania ecoinnovation 2015.pdf

\section{Research and Innovation Context}

According to „Research and Innovation performance in the EU”, country profile 2014 Report issued by the European Commission, „the key challenge for Romania remains its low level of competitiveness, which has significant consequences for the research and innovation system. The high-tech and medium-tech sectors of the economy do not contribute sufficiently to the trade balance, demand for knowledge remains weak, and the innovation culture continues to be underdeveloped". Romania is ranked as a modest innovator and has one of the lowest values in the EU for both R\&D intensity and business R\&D investments. There are several reasons for this situation, just naming a few: structure and fragmentation of the research system, underperforming Romanian Universities in all major international rankings, the low research activities in the business sector (only 29\% comparing to $64 \%$ the EU average), illustrated by the low number of patents and researchers employed by business and the low level of business R\&D intensity and cooperation with specialized institutes and academia [6].

\section{Interests and expectations of eco-innovation stakeholders in Romania}

During the period of July - December 2015, we have initiated a survey for the identification of organizations with potential to support the eco-innovation process in Romania.The results of the survey shows that the main interests in the field of ecoinnovation are related with education, service for companies and research. 


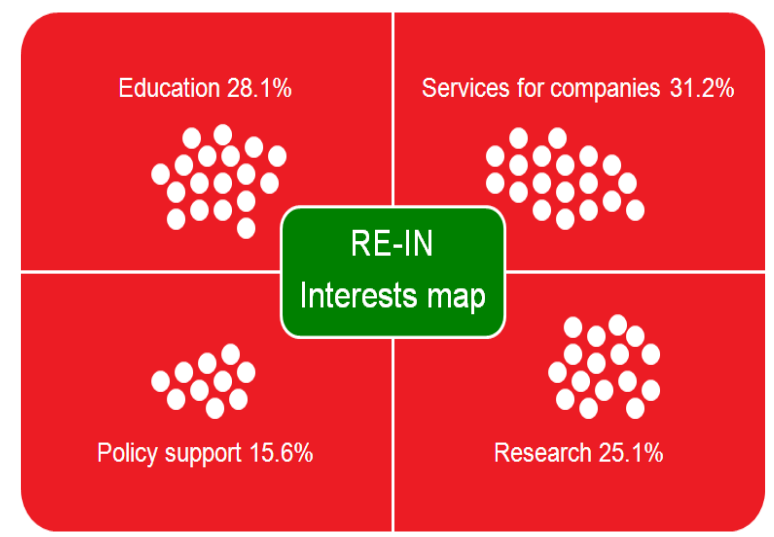

Figure 6: Results of the eco-innovation survey - interests of relevant stakeholders

Besides the survey and desk research, the research on eco-innovation in Romania was completed by direct consultations with stakeholders organized during joint meetings in Bucharest and Timisoara. The purpose was also to investigate the interests and expectations of the organizations regarding eco-innovation and to identify ways and methods to extend the application of the concept in Romania. The results of the consultations confirms the interests in education, policy support and cooperation but also identified the need for more promotion and awareness rising on the topic.

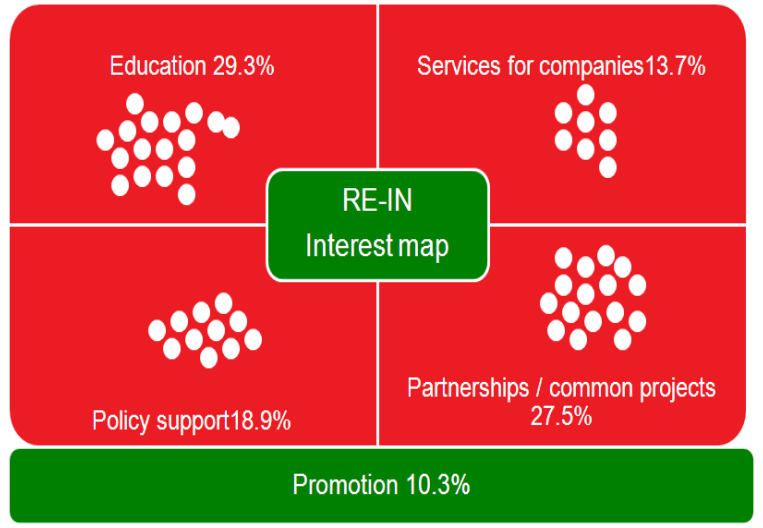

Figure 7: Results of the consultations with relevant stakeholders -interests and expectations regarding eco-innovation

The results of the survey and direct consultations shows high interest for cooperation in the fields of education, joint projects, promotion and awareness rising, integration of eco-innovation in universities' curricula, dissemination of information (articles, studies, etc.), development of public policies in the field of eco-innovation, eco-innovation support services for companies and support for institutional development.

The research activities have been performed under the framework of the ECOPartner project. EcoPartner is an of the first intiatives aiming to promote eco-innovation in Romania. The project is implemented by the National Centre for Sustainable Production and Consumption in cooperation with the Swiss partner, the Genevese Association for Development of Circular Economy and the Romanian Association of Clusters. (more information on www.cnpcd.ro) and is co-financed by a grant from Switzerland through the Swiss Contribution to the enlarged European Union. 


\section{Results and Discussion}

The results of the research on the context and conditions for eco-innovation in Romania refers to: barriers, premises and drivers.

The main identified barriers for eco-innovation refers to:

- Inconsistent legislative framework and mechanisms to support eco-innovative initiatives in industry and service sectors and to stimulate the development of green products and services;

- Poor understanding of economic and environmental benefits out of resource efficiency, waste and emissions minimization.

- Lack of awareness and understanding among the businesses, in particular SME's, of the life cycle thinking and the economic benefits that arise from ecoinnovative approaches

- Limited availability of funding towards cradle-to-cradle initiatives, or sustainable production and consumption projects..

- The limited technical knowledge of the existing experts and expert organizations and research institutions

- $\quad$ The lack of cooperation among the private and public sector and other key stakeholders in supporting adoption of eco-innovation

The main premises and drivers for eco-innovation are presented bellow

\begin{tabular}{|l|l|}
\hline Eco-innovation premises & Eco-innovation drivers \\
\hline $\begin{array}{l}\text { Well educated and highly innovative } \\
\text { human capital }\end{array}$ & $\begin{array}{l}\text { Continuous increase of prices for energy } \\
\text { and raw materials }\end{array}$ \\
\hline Increased access to information & $\begin{array}{l}\text { Increased competition on the EU open } \\
\text { market }\end{array}$ \\
\hline $\begin{array}{l}\text { Consumers with positive attitude } \\
\text { towards eco-products }\end{array}$ & $\begin{array}{l}\text { Increased legislative pressure to move } \\
\text { away from dangerous and pollutant } \\
\text { substances }\end{array}$ \\
\hline $\begin{array}{l}\text { Increased demand of ecofriendly } \\
\text { products from global supply chains }\end{array}$ & $\begin{array}{l}\text { Reputation and trust becomes essential } \\
\text { for a successful business }\end{array}$ \\
\hline $\begin{array}{l}\text { Increased access to financial } \\
\text { resources through EU programmes }\end{array}$ & Better access to capital \\
\hline Improved and harmonized legislation & More and higher environmental taxes \\
\hline & $\begin{array}{l}\text { New markets for eco and bio products } \\
\text { and services }\end{array}$ \\
\hline
\end{tabular}

Table 1: Premises and drivers for eco-innovation in Romania

\section{Conclusions}

Implementing eco-innovation is a challenging process and will not be suitable for all organizations. Therefore understating barriers and drivers at the national and business level and main gaps in policy and education could build a better picture of the context and conditions for eco-innovation in Romania.

The paper is reflecting existing opportunities in the country and demonstrates that ecoinnovation potential is important and needs to be addressed. Our research identified existing premises and drivers for eco-innovation that could boost application of eco- 
innovation in companies, entail policy changes, and boost cooperation between interested stakeholders from R\&D, academia, businesses, clusters and policy makers. Another conclusion is that barriers are more related to the supply side while the drivers shows that there is an increased demand for eco-innovation products, services and solutions. In this context, eco-innovation supply stimulation and support seems necessary through public policies and mechanism, financial and educational support for both public and private sector. Possible supply side measures can be drawn based on the taxonomy of eco-innovation policy.

\begin{tabular}{|c|c|c|}
\hline \multicolumn{3}{|c|}{ Supply-side support measures for eco-innovation } \\
\hline \multirow{5}{*}{ Finance } & Equity support & $\begin{array}{l}\text { Public venture capital funds } \\
\text { Mixed or subsidized private venture funds } \\
\text { Loss underwriting and guarantees } \\
\text { Tax incentives }\end{array}$ \\
\hline & Fiscal measures & $\begin{array}{l}\text { Corporation tax reductions for volume or increment } \\
\text { in R\&D } \\
\text { Reductions in the employment payroll tax and social } \\
\text { contributions } \\
\text { Personal tax incentives for R\&D workers }\end{array}$ \\
\hline & $\begin{array}{lr}\text { Support } & \text { for } \\
\text { public } & \text { sector } \\
\text { research } & \end{array}$ & $\begin{array}{l}\text { University funding } \\
\text { Laboratory funding } \\
\text { Collaborative grants } \\
\text { Strategic programmes for industry } \\
\text { Support for contract research } \\
\text { Equipment sharing }\end{array}$ \\
\hline & $\begin{array}{l}\text { Support for } \\
\text { training } \\
\text { mobility }\end{array}$ & $\begin{array}{l}\text { Tailored courses for firms } \\
\text { Entrepreneur ship training } \\
\text { Subsidized secondments } \\
\text { Industrial research studentships } \\
\text { Support for recruitment of scientists }\end{array}$ \\
\hline & $\begin{array}{l}\text { Grants for } \\
\text { industrial R\&D }\end{array}$ & $\begin{array}{l}\text { Grants for R\&D } \\
\text { Collaborative grants } \\
\text { Reimbursable loans } \\
\text { Prizes to spend on R\&D }\end{array}$ \\
\hline \multirow[t]{2}{*}{ Services } & $\begin{array}{l}\text { Information } \\
\& \quad \text { brokerage } \\
\text { support }\end{array}$ & $\begin{array}{l}\text { Contact databases } \\
\text { Brokerage events } \\
\text { Advisory services } \\
\text { International technology watch } \\
\text { Patent databases } \\
\text { Benchmarking }\end{array}$ \\
\hline & $\begin{array}{l}\text { Networking } \\
\text { measures }\end{array}$ & $\begin{array}{l}\text { Support for clubs } \\
\text { Foresight to build common visions } \\
\text { Co-location in incubators, Science parks }\end{array}$ \\
\hline
\end{tabular}

The success of eco-innovation depends on the awareness that will be created among businesses through dissemination of strong business cases, the adjustment of the policy framework that should stimulate and reward the market for eco-innovative solutions and the capacity of experts to convince the companies' management of the financial and environmental benefits of eco-innovation, to explain the need for 
continuous application of eco-innovative strategies and how they can be mainstreamed in the overall enterprise strategy and overall management.

For having an impact at a larger scale is essential to build cooperation and partnership within the key stakeholders and work with them to create a joint support and service offering that is more complete and compelling for the enterprises. Through its objectives, the ECOPartner project contributes to install a model of cooperation between main actors interested din eco-innovation, for supporting the enterprises and boost adoption of eco-innovation at the industry level, to build cooperation between the main stakeholders by initiating the Romanian Eco-Innovation Network (RE-IN). The role of the RE-IN is to develop and strength the partnership and to become the main partner in Romania for policy makers, businesses, academia and experts with common interests in eco-innovation.

\section{References}

[1] W. Steffen, W. Broadgate, L. Deutsch, O. Gaffney and C. Ludwig (2015), The Trajectory of the Anthropocene: the Great Acceleration, The Anthropocene Review. Map \& Design: Félix Pharand-Deschênes/Globaïa http://www.futureearth.org/blog/2015-jan-16/great-acceleration [2] Millennium Ecosystem Assessment, 2005- Ecosystems and Human Well-being: Synthesis. Island Press, Washington, DC

[3] OECD Directorate for Science, Technology and Industry (DSTI) - OECD Sustainable Manufacturing Toolkit, 2011, http://www.oecd.org/innovation/green/toolkit/48661768.pdf

[4] AselDoranova, Michal Miedzinski, Geert van der Veen, Alasdair Reid, Lorena Riviera Leon, Matthias Ploeg, MalinCarlberg, LiinaJoller - Technopolis Group, Business Models for Systemic Eco-innovations, 2012

http://www.technopolis-group.com/wp-content/uploads/2014/04/1524_EcoBM-EcoInnovation-Business-Models-assessment.pdf

[5] Eco-Innovation Observatory Report, 2013 - 2014, Eco-Innovation in Romania, Country Profile https://ec.europa.eu/environment/ecoap/sites/ecoap_stayconnected/files/romania_ecoinnovation_2015.pdf

[6] European Union Report, 2014 - "Research and Innovation performance in Romania, country profile 2014", http://ec.europa.eu/research/innovation-union/pdf/state-of-theunion/2014/countries/romania.pdf 